\title{
Assessment of Useful Alien Plant Species Cultivated and Managed in Rural Home Gardens of Limpopo Province, South Africa
}

\author{
Sebua Silas Semenya ${ }^{1}$ and Alfred Maroyi $\mathbb{i D}^{2}$ \\ ${ }^{1}$ Technology Transfer Office, Research Administration and Development Department, University of Limpopo, Private Bag X1106, \\ Sovenga 0727, Limpopo, South Africa \\ ${ }^{2}$ Department of Biodiversity, University of Limpopo, Private Bag X1106, Sovenga 0727, Limpopo, South Africa
}

Correspondence should be addressed to Alfred Maroyi; alfred.maroyi@gmail.com

Received 25 January 2020; Accepted 16 March 2020; Published 28 April 2020

Academic Editor: Francisco Ayuga

Copyright ( $\odot 2020$ Sebua Silas Semenya and Alfred Maroyi. This is an open access article distributed under the Creative Commons Attribution License, which permits unrestricted use, distribution, and reproduction in any medium, provided the original work is properly cited.

\begin{abstract}
Several communities in developing countries derive substantial part of their livelihood needs from alien plants cultivated and managed in home gardens. The aim of this study was to assess useful alien plant species cultivated and managed in home gardens of Limpopo province in South Africa. Semistructured interviews, personal observation, and guided walks with 300 participants between January 2015 and December 2016 were employed to obtain data on names of alien plants cultivated in home gardens and their use categories. A total of 101 plant species belonging to 44 families were recorded from the study area. More than half of the species (66.3\%) belonged to 14 families, Fabaceae, Asteraceae, Rosaceae, Solanaceae, Lamiaceae, Anacardiaceae, Poaceae, Amaranthaceae, Apocynaceae, Brassicaceae, Cactaceae, Euphorbiaceae, Moraceae, and Myrtaceae. Twenty-six use categories of alien plants were identified in this study with the majority of species (75.2\%) used for medicinal purposes, followed by ornamental (33.7\%), edible fruits (24.8\%), spices (16.8\%), vegetables (16.8\%), shade (11.9\%), beverages (10.9\%), construction materials ( $8.9 \%)$, firewood (7.9\%), and hedge (7.9\%). These findings corroborate the existing body of knowledge emphasizing the importance of plants grown and managed in home gardens to the livelihood needs of local communities.
\end{abstract}

\section{Introduction}

Plant species are an integral part of rural livelihoods in several rural communities across the African continent. Research by Cunningham [1] revealed that plant resources are important in the provision of construction poles, sources of food, medicine, shelter, building materials, fuel, and cash income. Similar research conducted in Cameroon [2, 3], Lesotho [4], Nigeria [5], and South Africa [6] revealed that a significant number of these species required for livelihoods needs are exotic plant species. These are species which have been introduced either intentionally or unintentionally into a country. Exotic species are usually divided into three categories, namely casual, naturalized, and invasive aliens $[7,8]$. According to Pyšek et al. [8], casual aliens reproduce occasionally outside cultivation, do not form self-sustaining populations, and rely on repeated introductions for their persistence. Naturalized species are defined as aliens that reproduce consistently without direct human intervention, while invasive aliens are defined as naturalized species producing offspring in large numbers and at considerable distances from the parent plants with the potential to spread over a large area. Many conservation practitioners and scientists regard the effects of invasive alien species in a largely negative light and advocate for scientists and government institutions to research and manage them, with huge budgets set aside for their detection and control $[9,10]$. The harmful ecological effects of alien plant species on natural ecosystems, economy, and human health are welldocumented with Shackleton and Shackleton [11] arguing that there is need to evaluate the positive and negative 
impacts of alien plant species on biodiversity, humankind, and economy. Some researchers also argue that several invasive species, especially those introduced purposefully, usually offer economic and intrinsic benefits, which can result in contentious issues and conflicts of interest surrounding their management, since some people may oppose certain forms or methods of control and want to derive benefits from these species [12-18]. Despite increasing evidence which show economic and intrinsic benefits of exotic plants, very few studies have documented such beneficial effects associated with such species. Most studies documenting the economic and intrinsic benefits of exotic plants appear to emphasize the medicinal value of these species. For example, Maroyi [19] documented the therapeutic value of alien plants in Zimbabwe and found that 26 species are used as herbal medicines for both human and animal ailments and diseases. A similar study conducted by Njoroge et al. [20] in Kenya reported 75 species from 34 plant families used as sources of traditional medicines against 59 human ailments. Borokini and Babalola [21] reviewed the utilization potential of eight exotic plant species used by Nigerians, and found that these species play a crucial role as sources of charcoal and herbal medicines. Several studies in Eastern Cape and Limpopo provinces in South Africa [22-29] focused on exotic plants used as herbal medicines in the country. Therefore, the present study was aimed at investigating the use values of alien plants cultivated and managed in the home gardens in Limpopo province of South Africa.

\section{Methodology}

2.1. Study Area. The present study was conducted in five districts namely Capricorn, Mopani, Sekhukhune, Waterberg, and Vhembe which constitute Limpopo province of South Africa (Figure 1). The Bapedi-speaking people constitute the largest cultural group in the province constituting $57.0 \%$ of the population [30]. Limpopo province receives mean annual rainfall ranging from $200 \mathrm{~mm}$ to $1500 \mathrm{~mm}$ and mean annual temperature ranging from $8^{\circ} \mathrm{C}$ to $32^{\circ} \mathrm{C}$ [31]. The major vegetation types in Limpopo province include bushveld, grassland, and forest biomes [32].

2.2. Data Collection. A multipurpose household survey was conducted from January 2015 to December 2016 with the aim of (i) randomly selecting the home gardens, (ii) informing the owners of chosen home gardens about the aim of the study, and (iii) requesting consent from informants to participate in data gathering and collection of voucher specimens. A total of 300 home gardens were assessed, resulting in 60 home gardens sampled per district. Information collected via semistructured interviews included sociodemographic characteristics of the participants, diversity of useful alien plant species, and how these species are used. The researchers collected, pressed, dried, and deposited voucher specimens at the University of Limpopo's Herbarium for documentation and reference purposes.
2.3. Data Analysis. Analyses of useful alien plant species were conducted using Statistical Package for the Social Sciences (SPSS) and Palaeontological Statistics [33]. The local importance of alien plant species was assessed using the relative frequency of citation (RFC). This index, proposed by Tardío and Pardo-de-Santayana [34], shows the local importance of each species, and it is a result of the frequency of citation (FC), the number of informants mentioning the use of the species divided by the total number of informants $(N)$, without considering the use categories [34, 35]. This index varies from 0 , where nobody refers to the plant as useful, to 1 in the likely case that all the informants would mention the use of the species.

$$
\mathrm{RCN}=\frac{\mathrm{FC}}{N} .
$$

\section{Results and Discussion}

3.1. Sociodemographic Characteristics of the Participants. Table 1 shows the demographic characteristics of the participants. The majority of participants belonged to the Bapedi ethnic group (60.0\%), and the remainder were Vhavenda and Vatsonga (20.0\% each). The majority of participants were females (73.3\%) compared to $26.7 \%$ males. Their ages ranged from 20 years to 77 years, with 38 years as the median. The majority $(63.3 \%)$ were between 31 years and 40 years of age; $16.6 \%$ were between 51 years and 60 years; $11.0 \%$, aged between 41 years and 50 years; $6.3 \%$, aged between 20 years and 30 years; and $2.6 \%$ were above 70 years of age. Majority of the participants were married with $53.7 \%$ of the men married, while $70.4 \%$ of the women were married. About three quarters of the participants (71.7\%) were educated up to secondary school level followed by $11.3 \%$ who were educated up to primary school level, 9.7\% had postsecondary qualifications, and $7.3 \%$ did not attend schooling. The main economic activity of the participants in this study was agriculture (48.0\%), followed by shop keeping (43.0\%), crafting (6.0\%), and livestock herding (3.0\%).

3.2. Plant Use and Taxonomic Diversity. A total of 101 plant species were recorded (Table 2) with herbs, trees, and shrubs having the most species (Figure 2). Pteridophytes and gymnosperms were represented by a single species each, Nephrolepis exaltata (L.) Schott (family Nephrolepidaceae) and Pinus patula Shiede ex SchItdl \& Cham (family Pinaceae). A large number $(66.3 \%)$ of the plant species recorded are from 14 families (Table 3), and the other 30 families had less representation, between one and two species each. Plant families with the highest number of species were Fabaceae (9 species), Asteraceae (8 species), Rosaceae and Solanaceae (7 species each), Lamiaceae (6 species), Anacardiaceae (5 species), Poaceae (4 species), and Amaranthaceae, Apocynaceae, Brassicaceae, Cactaceae, Euphorbiaceae, Moraceae, and Myrtaceae (3 species each) (Table 3). All these plant families with the exception of Moraceae are among the largest plant families in the world, characterized by at least 2000 species each [36]. 


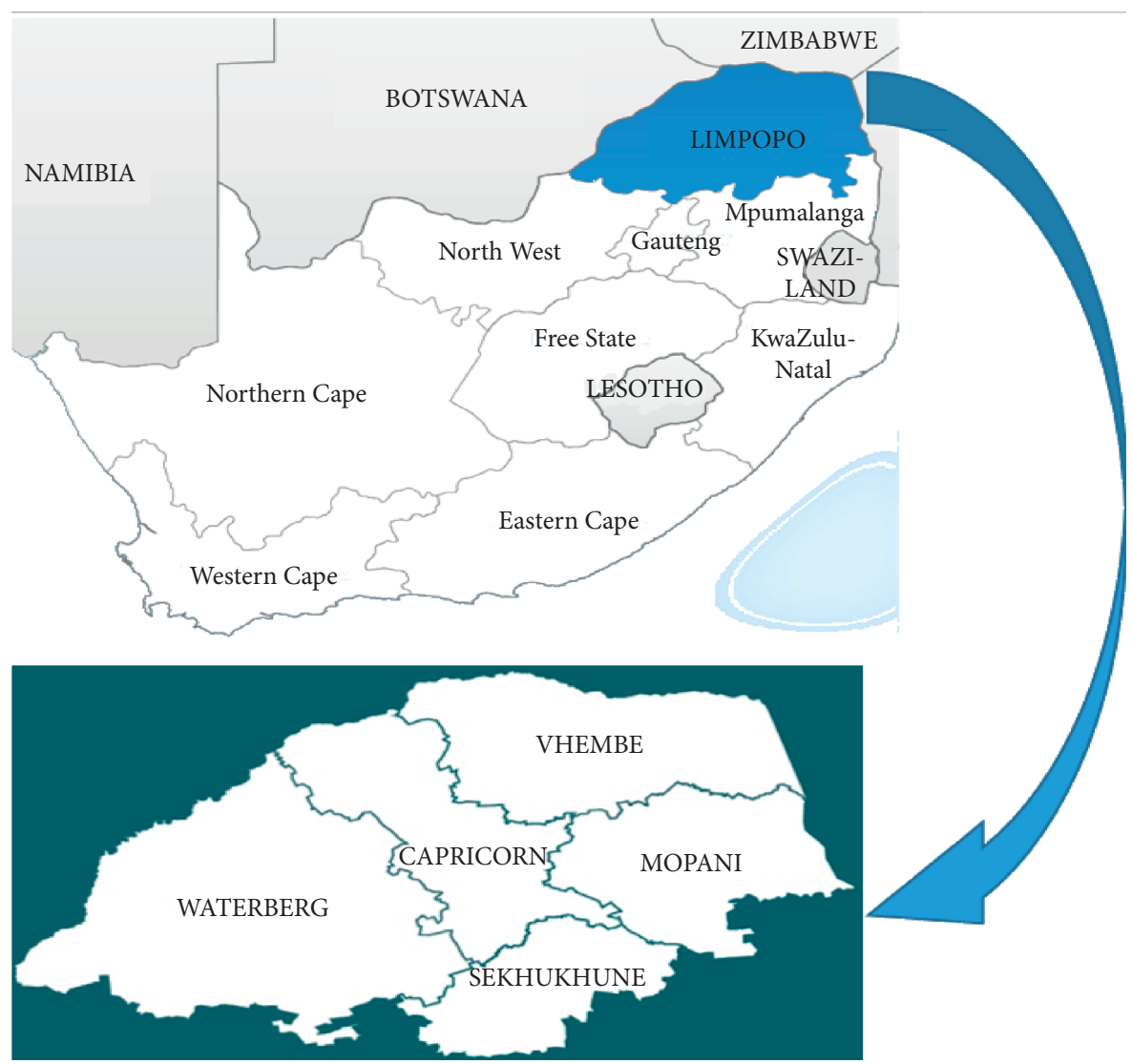

Figure 1: Map of Limpopo province indicating the studied areas.

TABLE 1: Socioeconomic characteristics of the study sample, $N=300$.

\begin{tabular}{lccc}
\hline & Socioeconomic variables & Number & $\%$ \\
\hline \multirow{3}{*}{ Ethnic groups } & Bapedi & 180 & 60.0 \\
& Vhavenda & 60 & 20.0 \\
& Vatsonga & 60 & 20.0 \\
\hline \multirow{2}{*}{ Gender } & Female & 220 & 73.3 \\
& Male & 80 & 26.7 \\
\hline \multirow{4}{*}{ Age (years) } & $<30$ & 12 & 4.0 \\
& $21-30$ & 19 & 6.3 \\
& $31-40$ & 170 & 56.7 \\
& $41-50$ & 46 & 15.3 \\
& $51-60$ & 32 & 10.7 \\
& $61-70$ & 13 & 4.3 \\
\multirow{4}{*}{ Marital status } & $>70$ & 8.7 \\
& Single (males) & 7.3 \\
& Single (females) & 13.7 \\
& Married (males) & 14.3 \\
Highest level of education & Married (females) & 51.7 \\
& Divorced or separated (males) & 5.0 \\
& Divorced or separated (females) & 41 & 8.0 \\
\hline \multirow{4}{*}{ Economic activity } & No education & 155 & 7.3 \\
& Primary & 15 & 11.3 \\
& Secondary & 24 & 71.7 \\
& Tertiary & 22 & 9.7 \\
\hline
\end{tabular}




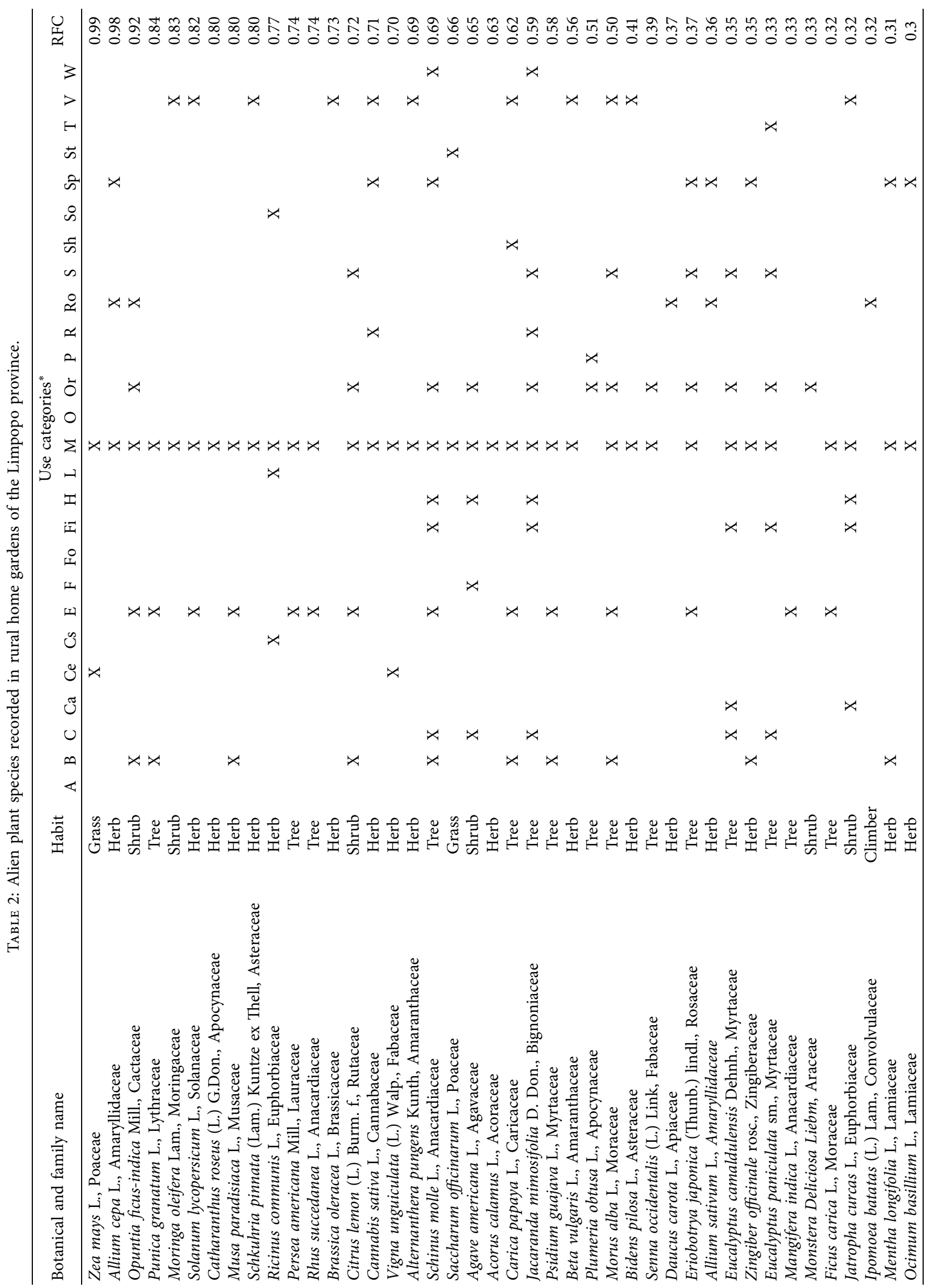




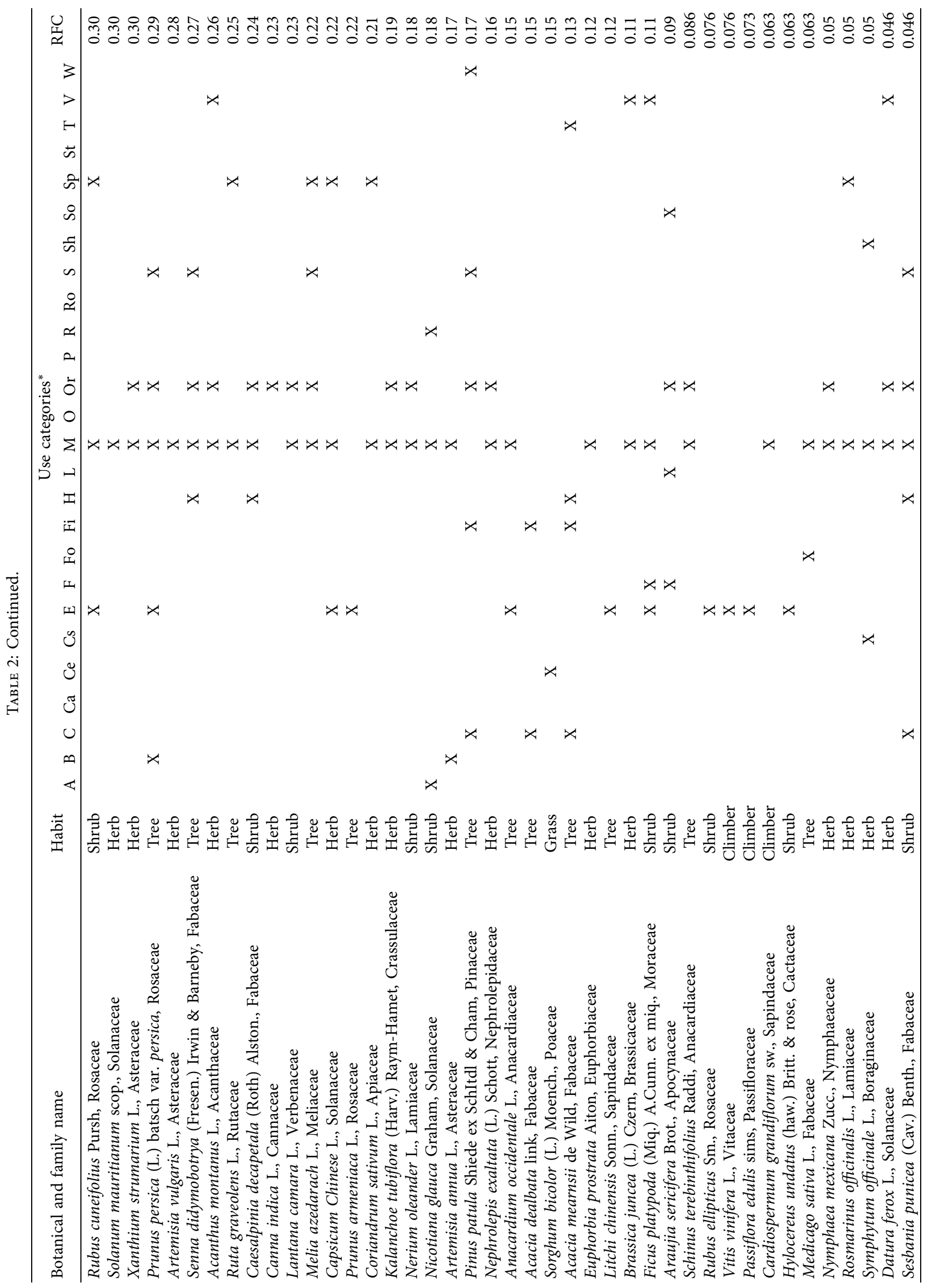




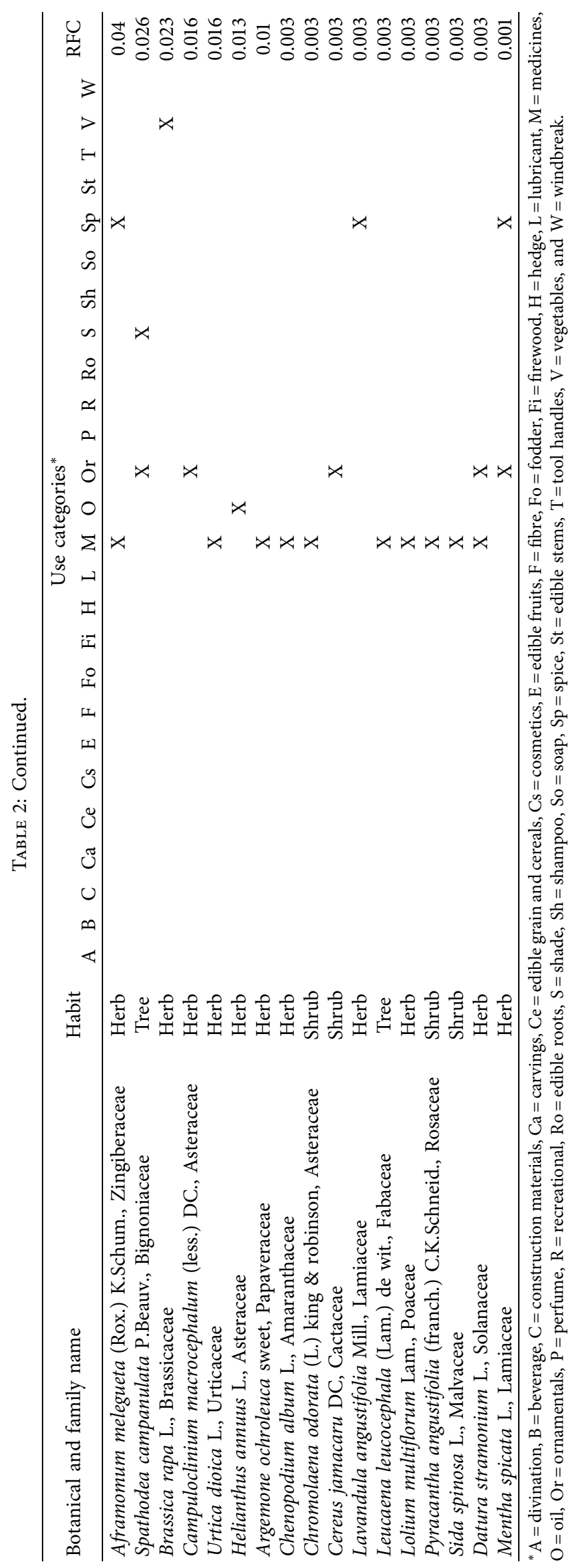




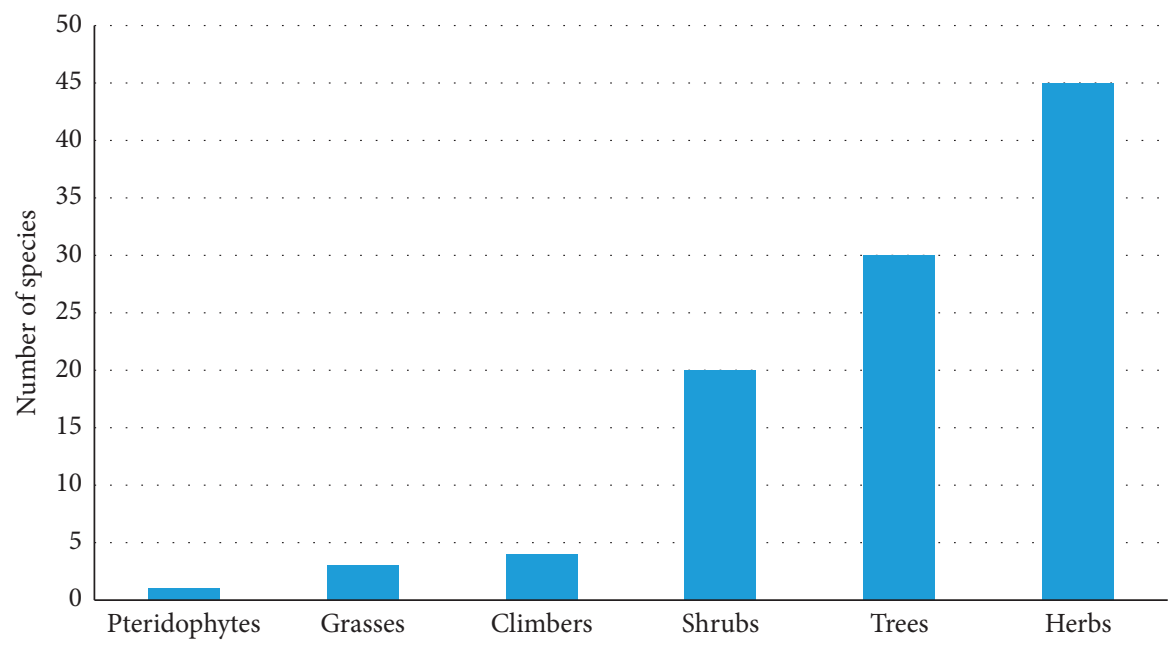

FIGURE 2: Growth forms of alien plant species recorded in rural home gardens of Limpopo province.

TABLE 3: Plant families with the largest number of alien species (with at least three species) in rural home gardens of Limpopo province.

\begin{tabular}{lcc}
\hline Family & Number of species & $\%$ \\
\hline Fabaceae & 9 & 8.9 \\
Asteraceae & 8 & 7.9 \\
Rosaceae & 7 & 6.9 \\
Solanaceae & 7 & 6.9 \\
Lamiaceae & 6 & 5.9 \\
Anacardiaceae & 5 & 5.0 \\
Poaceae & 4 & 4.0 \\
Amaranthaceae & 3 & 3.0 \\
Apocynaceae & 3 & 3.0 \\
Brassicaceae & 3 & 3.0 \\
Cactaceae & 3 & 3.0 \\
Euphorbiaceae & 3 & 3.0 \\
Moraceae & 3 & 3.0 \\
Myrtaceae & 3 & 3.0 \\
\hline
\end{tabular}

3.3. Plant Use Categories Based on Relative Frequency Citation (RFC) Values. Twenty-six use categories of alien plants were identified in this study (Table 2, Figure 3). Relative frequency citation values determined in this study indicated that alien species used to facilitate divination and other spiritual healing rituals $(\mathrm{A}, \mathrm{RFC}=0.73)$ and used as edible grain and cereals $(\mathrm{Ce}, \quad \mathrm{RFC}=0.15-0.99)$, edible fruits $(\mathrm{E}$, $\mathrm{RFC}=0.04-0.76)$, roots $(\mathrm{Ro}, \mathrm{RFC}=0.32-0.55)$, and stems $(\mathrm{St}, \mathrm{RFC}=0.66)$ were characterized by the highest values (Figure 3). The RFC shows the importance of each species based on the number of participants citing the species [35]. The RFC values of different species' use categories were summed resulting in a numerical value that was used to rank the species in order of importance displayed in Table 2. The species with RFC values $\geq 0.8$ were Zea mays $\mathrm{L}$. (cereal and herbal medicine), Allium cepa L. (herbal medicine and spice), Opuntia ficus-indica Mill. (beverage, edible fruits, herbal medicine, ornamental, and edible roots), Punica granatum L. (beverage, edible fruits, and herbal medicines), Moringa oleifera Lam. (herbal medicine and vegetable), Solanum lycopersicon L. (edible fruits, herbal medicine, and vegetable), Catharanthus roseus (L.) G.Don. (herbal medicine), Musa paradisiaca L. (beverage, edible fruits, and herbal medicine), and Schkuhria pinnata (Lam.) Kuntze ex Thell (herbal medicine and vegetable) (Table 2). Assessment of RFC values in relation to use categories resulted in grouping plant species recorded in this study into two clusters, A and B, as shown in Figure 4. Cluster $\mathrm{A}$ is composed of species characterized by RFC values which are below 0.5 and use values which are less than six while cluster $\mathrm{B}$ is composed of species with RFC values which are higher than 0.5 and number of use values which are as high as nine (Figure 4). Multipurpose species within cluster B characterized by at least three use categories and RFC values $\geq 0.5$ included Allium cepa L., Opuntia ficus-indica Mill., Punica granatum L., Musa paradisiaca L., Ricinus communis L., Citrus lemon (L.), Burm. f., Cannabis sativa L., Schinus molle L., Agave americana L., Carica papaya L., Jacaranda mimosifolia D. Don., Psidium guajava L., and Morus alba L. (Table 2).

The majority of plant species recorded in this study (75.2\%) were used for medicinal purposes, followed by ornamental plants $(33.7 \%)$, edible fruits (24.8\%), spices (16.8\%), vegetables (16.8\%), shade (11.9\%), beverages $(10.9 \%)$, construction materials $(8.9 \%)$, firewood $(7.9 \%)$, and hedge $(7.9 \%)$ (Figure 5$)$. These results correlate with previous research findings from South Africa [37, 38] and other countries like Brazil [39], Iberian Peninsula [40], and India [41] which found that the majority of exotic plant species in the home gardens are used as traditional medicines. High usage of species for medicinal purposes in the Limpopo province is not surprising as the province is characterized by inadequate modern health care services and shortage of pharmaceutical drugs for different ailments. Recent research by Ntuli and Maboya [42] showed that there is a shortage of medical doctors and maladministration of public sector hospitals in the rural areas of the Limpopo province, with the majority of medical doctors employed in urban areas. There is now overwhelming evidence that alien plant species are used widely as herbal medicines and are now recognized as an important component of indigenous pharmacopoeia in 


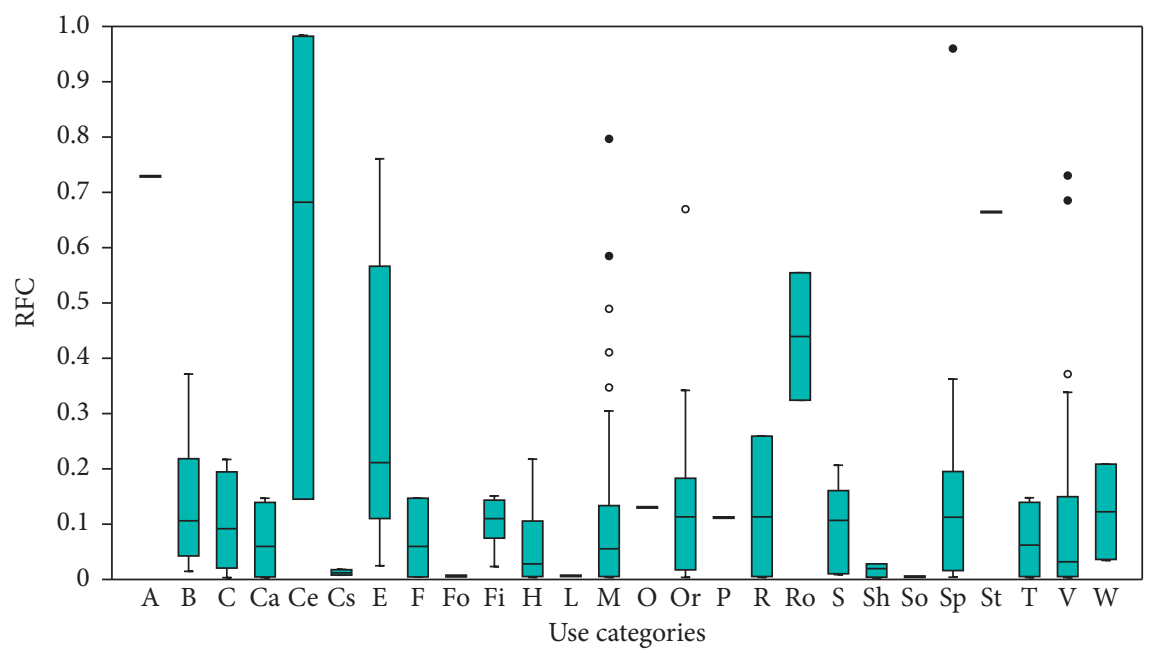

FIGURE 3: Relationship of relative frequency citation (RFC) and use categories of alien plants in home gardens in Limpopo province, South Africa. Conventions: $\mathrm{A}=$ facilitate divination, $\mathrm{B}=$ beverage, $\mathrm{C}=$ construction materials, $\mathrm{Ca}=$ carvings, $\mathrm{Ce}=$ edible grain and cereals, $\mathrm{Cs}=$ cosmetics, $\mathrm{E}=$ edible fruits, $\mathrm{F}=$ fibre, $\mathrm{Fo}=$ fodder, $\mathrm{Fi}=$ firewood, $\mathrm{H}=$ hedge, $\mathrm{L}=$ lubricant, $\mathrm{M}=$ medicines, $\mathrm{O}=\mathrm{oil}, \mathrm{Or}=$ ornamentals, $\mathrm{P}=$ perfume, $\mathrm{R}=$ recreational, $\mathrm{Ro}=$ edible roots, $\mathrm{S}=$ shade, $\mathrm{Sh}=$ shampoo, So=soap, $\mathrm{Sp}=$ spice, $\mathrm{St}=$ edible stems, $\mathrm{T}=$ tool handles, $\mathrm{V}=$ vegetables, and $\mathrm{W}=$ windbreak.

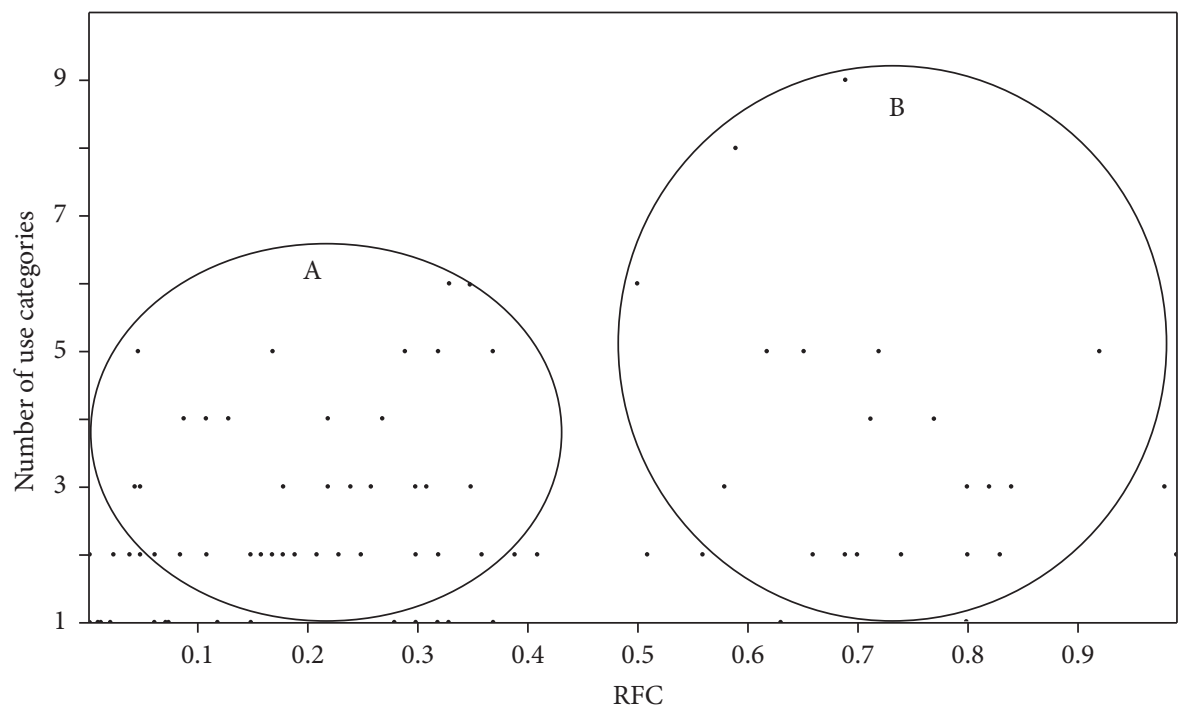

FIGURE 4: Relationship between the number of use categories and relative frequency citation (RFC) of alien plants in home gardens in Limpopo province, South Africa.

several countries [43-46]. Research by Palmer [44] and Alencar et al. $[45,46]$ revealed that utilization of alien plants as herbal medicines is a result of experimentations conducted for several years and represents an adaptation of this culture over time. Therefore, alien plants are included in traditional pharmacopoeias to fill therapeutic vacancies that native plants cannot satisfy [43-46].

The recorded food plants were used as beverage, edible grain and cereals, edible fruits, roots, stems, and spices (Table 2). The majority (40.3\%) of recorded food plants were consumed raw and these included Anacardium occidentale L., Carica papaya, Citrus lemon, Eriobotrya japonica L., Ficus carica L., Ficus platypoda (Miq.) A.Cunn. ex Miq., Morus alba L., Musa paradisiaca L., Opuntia ficus-indica, Persea americana Mill., Prunus persica (L.) Batch var. persica, Psidium guajava L., Punica granatum L., Rhus succedanea L., Rubus cuneifolius Pursh, and Schinus molle L. Some species which included Hylocereus undatus (Haw.) Britt. \& Rose, Litchi chinensis Sonn., Mangifera indica L., Passiflora edulis Sims, Prunus armeniaca L., Prunus persica, Rubus ellipticus Pursh, and Vitis vinifera L. were managed in home gardens for their edible fruits. About a third of the documented species $(29.0 \%)$ were consumed as vegetables and these included Acanthus montanus L., Alternanthera pungens Kunth, Bidens pilosa L., Cannabis sativa L., Datura ferox L., Schkuhria pinnata (Lam.) Kuntze ex Tehell, Beta vulgaris L., Ficus platypoda, Solanum lycopersicum L., Brassica juncea (L.) Czern, Brassica oleracea L., Brassica rapa L., Carica 


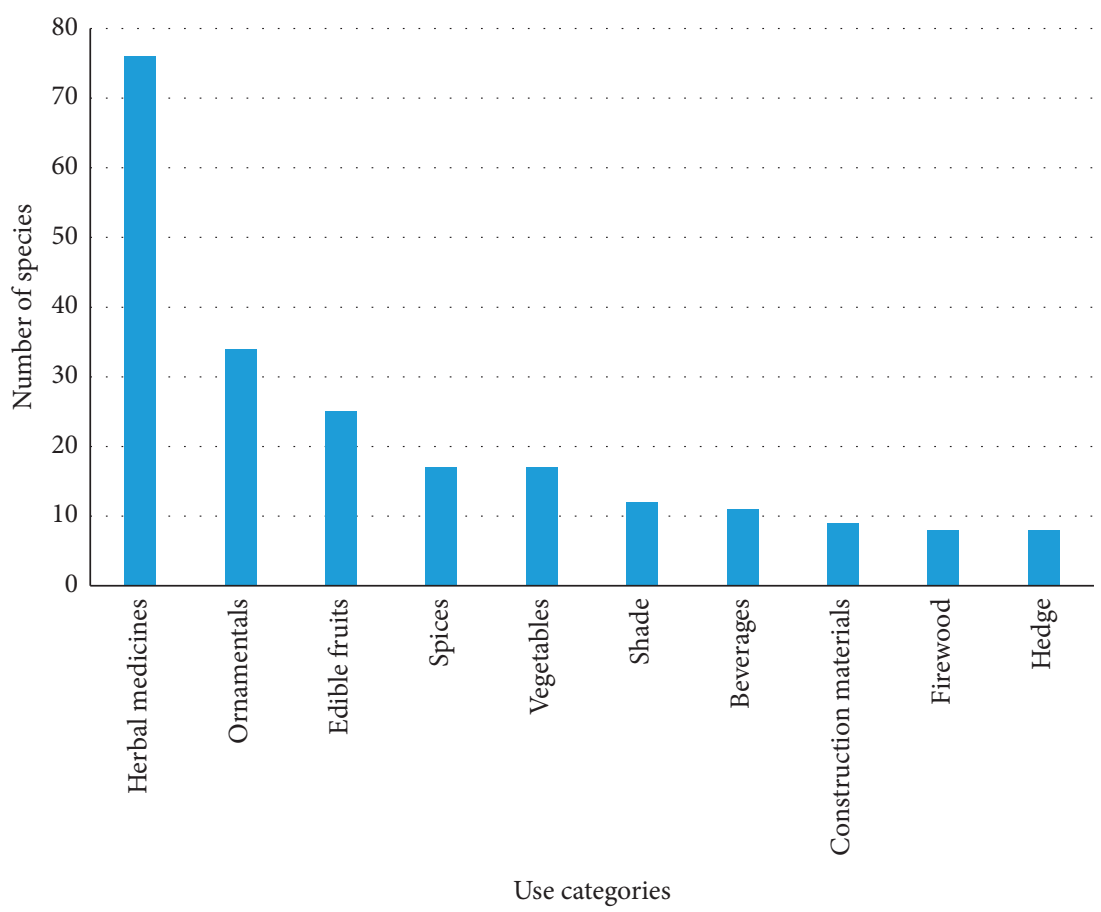

FIGURE 5: Major use categories of exotic plants in home gardens in Limpopo province.

papaya, Jatropha curcas L., Solanum lycopersicum, Moringa oleifera Lam., and Morus alba. The vegetables managed in home gardens were eaten as relish to complement staple diet prepared from maize meal (Zea mays L.). The plants species used as spices (20.9\%) included Allium sativum L., Lavandula angustifolia Mill., Mentha spicata L., Aframomum melegueta (Rox.) K.Schum., Capsicum Chinese L., Coriandrum sativum L., Melia azedarach L., Mentha longifolia L., Ocimum basillium L., Rosmarinus officinalis L., Ruta graveolens L., and Zingiber officinale Rosc. The remaining species which constituted the food category in the present study were consumed as beverages and these included $\mathrm{Ar}$ temisia annua L., Mentha longifolia, and Zingiber officinale, edible grain and cereals (Sorghum bicolor (L.) Moench., Vigna unguiculata (L.) Walp., and Zea mays), edible tubers (Daucus carota L. and Ipomoea batatas (L.) Lam.), and edible stems (Saccharum officinarum L.) and used as cooking oil (Helianthus annuus L.). Research by Gosh [47] showed that local food production in the home gardens could meaningfully contribute towards building a sustainable food production for the household and local community. Similarly, Kamiyama et al. [48] argued that there is need to strengthen food production in local communities through improved production in home gardens to mitigate growing global food instability.

The proportion of ornamental plants was about a third (33.6\%) to the overall use categories of the home garden alien flora in Limpopo province. The majority of these species were categorized as multipurpose species with Campuloclinium macrocephalum (Less.) DC., Canna indica L., Cereus jamacaru DC., Mentha spicata, Monstera deliciosa Liebm, and Spathodea campanulata P.Beauv. exclusively cultivated and managed as ornamental plants (Table 2). The relevance of ornamental plants in home gardens varies in different countries. Research by Aworinde et al. [49] revealed that food and medicinal plants were more abundant than ornamental plants but research findings of Neulinger et al. [50] revealed the opposite, with ornamental plants exceeding both food and medicinal plants. Therefore, the importance of ornamental plants in home gardens should not be underestimated and Hurrel [51] argued that ornamentals have been employed by humans throughout history for aesthetic and symbolic values. Similarly, only nine species which included Acacia dealbata Link, Acacia mearnsii De Wild, Agave americana L., Eucalyptus camaldulensis Dehnh., Eucalyptus paniculata Sm., Jacaranda mimosifolia D. Don., Pinus patula Shiede ex SchItdl and Cham, Schinus molle L., and Sesbania punicea (Cav.) Benth. were used as sources of timber and construction materials (Table 2). Plant species such as Acacia dealbata, Acacia mearnsii, Agave Americana, Eucalyptus camaldulensis, Eucalyptus paniculata, and Jacaranda mimosifolia are widely cultivated in other countries such as Ethiopia, Kenya, and Mexico as sources of timber and construction materials [52-54]. Species used as sources of firewood included Acacia dealbata, Acacia mearnsii, Eucalyptus camaldulensis, Eucalyptus paniculata, Jacaranda mimosifolia, Jatropha curcas, and Schinus molle (Table 2).

\section{Conclusions}

Due to high diversity of alien species cultivated and managed in home gardens in Limpopo province and the associated wide range of use categories of these species, it implies that home gardens could be important sources of goods and ecosystem services needed by local communities. Results of this study corroborate the existing body of knowledge 
emphasizing the importance of plants that are grown and managed in home gardens. Exploitation of plants cultivated and maintained in home gardens has played an important role in the provision of livelihood needs of local communities. Future research needs to quantify the goods and ecosystem services provided by alien plants. Such detailed studies are needed to understand the importance of alien species in the provision of livelihood needs. We conclude that future management polices focusing on alien plants should take into consideration the positive attributes of such plant species.

\section{Data Availability}

All data associated with the manuscript have been included in the tables and figures.

\section{Conflicts of Interest}

The authors declare that there are no conflicts of interest.

\section{Acknowledgments}

The authors are grateful to local communities in Limpopo province for participating in this study and sharing their valuable knowledge on useful plants cultivated and managed in their home gardens.

\section{References}

[1] A. B. Cunningham, "An Africa-wide overview of medicinal plant harvesting, conservation and health care," Nonwood Forrest Products, vol. 11, pp. 16-129, 1997.

[2] D. A. Focho, M. C. Newu, M. G. Anjah, F. A. Nwana, and F. B. Nwana, "Ethnobotanical survey of trees in fundong, northwest region, Cameroon," Journal of Ethnobiology and Ethnomedicine, vol. 5, no. 1, 2009.

[3] A. E. Egbe, P. T. Tabot, and B. A. Fonge, "Ethnobotany of some selected tree species in southwest Cameroon," Ethnobotany Research and Applications, vol. 10, pp. 235-246, 2012.

[4] A. Moteetee and B.-E. Van Wyk, "Sesotho names for exotic and indigenous edible plants in southern Africa," Bothalia, vol. 36, no. 1, pp. 25-32, 2006.

[5] A. S. Kutama, I. I. Dangora, W. A. Aisha et al., "An overview of plant resources and their economic uses in Nigeria," Global Advanced Research Journal of Agricultural Science, vol. 4, no. 2, pp. 42-67, 2015.

[6] A. Maroyi, "Diversity of use and local knowledge of wild and cultivated plants in the Eastern Cape province, South Africa," Journal of Ethnobiology and Ethnomedicine, vol. 13, no. 1, 2017.

[7] D. M. Richardson, P. Pyšek, M. Rejmánek, M. G. Barbour, F. D. Panetta, and C. J. West, "Naturalization and invasion of alien plants: concepts and definitions," Diversity, vol. 6, pp. 93-107, 2000.

[8] P. Pyšek, D. M. Richardson, M. Rejmánek et al., “Alien plants in checklists and flora: towards better communication between taxonomists and ecologists," Taxon, vol. 53, no. 1, pp. 131-143, 2004.

[9] B. D. Hoffmann and L. M. Broadhurst, "The economic cost of managing invasive species in Australia," NeoBiota, vol. 31, no. 1, pp. 1-18, 2016.
[10] B. W. Van Wilgen and A. Wannenburgh, "Co-facilitating invasive species control, water conservation and poverty relief: achievements and challenges in South Africa's Working for Water programme," Current Opinion in Environmental Sustainability, vol. 19, no. 1, pp. 7-17, 2016.

[11] S. E. Shackleton and R. T. Shackleton, "Local knowledge regarding ecosystem services and disservices from invasive alien plants in the arid Kalahari, South Africa," Journal of Arid Environments, vol. 159, no. 1, pp. 22-33, 2018.

[12] A. Olszańska, W. Solarz, and K. Najberek, "To kill or not to kill: practitioners' opinions on invasive alien species management as a step towards enhancing control of biological invasions," Environmental Science and Policy, vol. 58, pp. 107-116, 2016.

[13] S. L. Crowley, S. Hinchliffe, and R. A. McDonald, "Conflict in invasive species management," Frontiers in Ecology and the Environment, vol. 15, no. 3, pp. 133-141, 2017.

[14] A. S. Vaz, C. Kueffer, C. A. Kull et al., "Integrating ecosystem services and disservices: insights from plant invasions," Ecosystem Services, vol. 23, pp. 94-107, 2017.

[15] T. Zengeya, P. Ivey, D. J. Woodford et al., "Managing conflictgenerating invasive species in South Africa: challenges and trade-offs," Bothalia, vol. 47, pp. 1-11, 2017.

[16] T. M. Bach, C. A. Kull, and P. Rangan, "From killing lists to healthy country: aboriginal approaches to weed control in Kimberly, Western Australia," Journal of Environmental Management, vol. 229, pp. 182-192, 2019.

[17] R. T. Shackleton, D. M. Richardson, C. M. Shackleton et al., "Explaining people's perceptions of invasive alien species: a conceptual framework," Journal of Environmental Management, vol. 229, pp. 10-26, 2019.

[18] F. J. Villatoro, L. Naughton-Treves, M. Sepúlveda et al., "When free-ranging dogs threaten wildlife: public attitudes toward management strategies in southern Chile," Journal of Environmental Management, vol. 229, pp. 67-75, 2019.

[19] A. Maroyi, "Ethnomedicinal uses of exotic plant species in South Central Zimbabwe," Indian Journal of Traditional Knowledge, vol. 17, no. 1, pp. 71-77, 2018.

[20] N. G. Njoroge, W. R. Bussmann, B. Gemmill et al., "Utilisation of weed species as sources of traditional medicines in central Kenya," Lyonia, vol. 7, no. 2, pp. 71-87, 2004.

[21] T. I. Borokini and F. D. Babalola, "Management of invasive plant species in Nigeria through economic exploitation: lessons from other countries," Management of Biological Invasions, vol. 3, no. 1, pp. 45-55, 2012.

[22] A. P. Dold and M. L. Cocks, "The medicinal use of some weeds, problem and alien plants in the Grahamstown and Peddie districts of the Eastern Cape, South Africa," South African Journal of Science, vol. 96, pp. 467-473, 2000.

[23] F. B. Lewu and A. J. Afolayan, "Ethnomedicine in South Africa: the role of weedy species," African Journal of Biotechnology, vol. 8, no. 6, pp. 929-934, 2009.

[24] S. S. Semenya, M. P. Tshisikhawe, and M. J. Potgieter, "Invasive alien plant species: a case study of their use in the Thulamela local municipality, Limpopo Province, South Africa," Scientific Research and Essays, vol. 7, no. 27, pp. 2363-2369, 2012.

[25] S. S. Semenya, M. J. Potgieter, M. P. Tshisikhawe et al., "Medicinal utilization of exotic plants by Bapedi traditional healers to treat human ailments in Limpopo Province, South Africa," Journal of Ethnopharmacology, vol. 144, no. 3, pp. 646-655, 2012.

[26] L. P. Maema, M. J. Portgieter, and S. M. Mahlo, "Invasive alien plant species used for the treatment of various diseases in 
Limpopo Province, South Africa," African Journal of Traditional Complementary and Alternative Medicine, vol. 13, no. 4, pp. 223-231, 2016.

[27] L. P. Maema, M. J. Portgieter, and A. Samie, "Ethnobotanical survey of invasive alien plant species used in the treatment of sexually transmitted infections in Waterberg district, South Africa," South African Journal of Botany, vol. 122, pp. 391-400, 2019.

[28] S. G. Mbambala, M. P. Tshisikawe, and N. A. Masevhe, "Invasive alien plants used in the treatment of HIV/AIDSrelated symptoms by traditional healers of Vhembe Municipality, Limpopo province, South Africa," African Journal of Traditional Complementary and Alternative Medicine, vol. 14, no. 5, pp. 80-88, 2017.

[29] S. S. Semenya and A. Maroyi, "Exotics plants used therapeutically by Bapedi traditional healers for respiratory infections and related symptoms in the Limpopo province, South Africa," Indian Journal of Traditional Knowledge, vol. 17, no. 4, pp. 663-671, 2018.

[30] T. Lodge, "Provincial government and state authority in South Africa," Journal of Southern African Studies, vol. 31, no. 4, pp. 748-749, 2005.

[31] E. Mosase and L. Ahiablame, "Rainfall and temperature in the Limpopo river basin, Southern Africa: means, variations, and trends from 1979 to 2013," Water, vol. 10, p. 364, 2018.

[32] L. Mucina and M. C. Rutherford, The Vegetation of South Africa, Lesotho and Swaziland, South African National Biodiversity Institutes, Pretoria, South Africa, 2006.

[33] Ø. Hammer, D. A. T. Harper, and R. D. Ryan, "PAST: palaeontological statistics software package for education and data analysis," Palaeontologia Electronica, vol. 4, no. 1, pp. 1-9, 2001.

[34] J. Tardío and M. Pardo-de-Santayana, "Cultural importance indices: a comparative analysis based on the useful wild plants of southern Cantabria (Northern Spain)," Economic Botany, vol. 62 , no. 1 , pp. 24-39, 2008.

[35] S. Vitalini, M. Iriti, C. Puricelli et al., "Traditional knowledge on medicinal and food plants used in Val San Giacomo (Sondrio, Italy) an Alpine ethnobotanical study," Journal of Ethnopharmacology, vol. 145, no. 2, pp. 517-529, 2013.

[36] J. M. Christenjusz, M. F. Fay, and M. W. Chase, Plants of the World: An Illustrated Encyclopedia of Vascular Plants, Kew Publishing, Royal Botanic Gardens, London, UK, 2017.

[37] A. O. Nemudzudzanyi, S. J. Siebert, A. M. Zobolo et al., "The Zulu Muzi: a homegarden system of useful plants with a specific layout and function," Indilinga African Journal of Indigenous Knowledge Systems, vol. 9, no. 1, pp. 57-72, 2010.

[38] G. K. E. Mosina, A. Maroyi, and M. J. Potgieter, "Useful plants grown and maintained in domestic gardens of the Capricorn District, Limpopo province, South Africa," Studies on Ethnomedicine, vol. 9, no. 1, pp. 43-58, 2015.

[39] L. L. D. Santos, A. L. B. Nascimento, F. B. Vieira et al., "The cultural value of invasive species: a case study from semi-arid northeastern Brazil," Economic Botany, vol. 68, no. 3, pp. 283-300, 2014.

[40] A. Agelet, M. A. Bonet, and J. Valles, "Homegardens and their role as a main source of medicinal plants in mountain regions of Catalonia (Iberian Peninsula)," Economic Botany, vol. 53, no. 3, pp. 295-309, 2000.

[41] S. Bajpai, A. K. Sharma, and V. K. Kanungo, "Traditional home gardens: a preserve of medicinal plants," International Journal of Herbal Medicine, vol. 1, no. 2, pp. 152-161, 2013.

[42] S. T. Ntuli and E. Maboya, "Geographical distribution and profile of medical doctors in public sector hospitals of the
Limpopo Province, South Africa," African Journal of Primary Health Care and Family Medicine, vol. 9, no. 1, p. a1443, 2017.

[43] B. C. Bennett and G. T. Prance, "Introduced plants in the indigenous pharmacopoeia of northern south America," Economic Botany, vol. 54, no. 1, pp. 90-102, 2000.

[44] C. T. Palmer, "The inclusion of recently introduced plants in the Hawaiian Ethnopharmacopoeia," Economic Botany, vol. 58, pp. S280-S293, 2004.

[45] N. L. Alencar, T. A. A. de Sousa, E. L. C. de Amorim et al., "The inclusion and selection of medicinal plants in traditional pharmacopoeias: evidence in support of the diversification hypothesis," Economic Botany, vol. 64, no. 1, pp. 68-79, 2010.

[46] N. L. Alencar, F. R. Santoro, and U. P. de Albuquerque, "What is the role of exotic medicinal plants in local medical systems? A study from the perspective of utilitarian redundancy," Revista Brasileira de Farmacognosia, vol. 24, no. 5, pp. 506515, 2014.

[47] S. Ghosh, "Measuring sustainability performance of local food production in home gardens," Local Environment, vol. 19, no. 1, pp. 33-55, 2014.

[48] C. Kamiyama, S. Hashimoto, R. Kohsaka et al., "Non-market food provisioning services via homegardens and communal sharing in satoyama socio-ecological production landscapes on Japan's Noto peninsula," Ecosystem Services, vol. 17, pp. 185-196, 2016.

[49] D. O. Aworinde, S. M. Erinoso, B. O. Ogundairo et al., "Assessment of plants grown and maintained in home gardens in Odeda area, Southwestern Nigeria," Journal of Horticulture and Forestry, vol. 5, no. 2, pp. 29-36, 2013.

[50] K. Neulinger, C. R. Vogl, and J. A. A. Gamboa, "Plant species and their uses in homegardens of migrant Maya and Mestizo smallholder farmers in Calakmul, Campeche, Mexico," Journal of Ethnobiology, vol. 33, no. 1, pp. 105-124, 2013

[51] J. A. Hurrel, "Ornamental plants," in Introduction to Ethnobiology, U. P. Albuquerque and R. R. N. Alves, Eds., pp. 171-175, Springer International Publishing, New York, NY, USA, 2016.

[52] I. Blanckaert, R. L. Swennen, M. Flores et al., "Floristic composition, plant uses and management practices in homegardens of San Rafael Coxcatlan, valley of TehuacanCuicatlan, Mexico," Journal of Arid Environments, vol. 57, no. 1, pp. 39-62, 2004.

[53] J. Machua, G. Muturi, S. F. Omondi et al., "Genetic diversity of Jatropha curcas L. populations in Kenya using RAPD molecular markers: implication to plantation establishment," African Journal of Biotechnology, vol. 10, no. 16, pp. 30623069, 2011.

[54] T. Mekonen, M. Giday, and E. Kelbessa, "Ethnobotanical study of homegarden plants in Sebeta-Awas District of the Oromia Region of Ethiopia to assess use, species diversity and management practices," Journal of Ethnobiology and Ethnomedicine, vol. 11, no. 64, 2015. 